\title{
Analisis Perbedaan Abnormal Return dan Trading Volume Activity Pada Sekitar Cum Dividend Date
}

\author{
(Analysis of Differences Abnormal Return and Trading Volume Activity on \\ Cum Dividend Date)
}

\author{
Tias Marganing Sih*, Tatang Ary Gumanti, Hadi Paramu \\ Jurusan Manajemen, Fakultas Ekonomi dan Bisnis, Universitas Jember (UNEJ) \\ Jln. Kalimantan 37, Jember 68121 \\ E-mail: marganingtias@gmail.com
}

\begin{abstract}
Abstrak
Tujuan dari penelitian ini adalah untuk menganalisis perbedaan Abnormal Return dan Trading Volume Activity pada masingmasing sektor saham pada sekitar cum dividend date. Populasi pada penelitian ini adalah semua perusahaan yang tercatat pada Bursa Efek Indonesia (BEI), pengambilan sampel dilakukan dengan metode purpusive sampling dan didapatkan 156 sampel. Metode analisis yang digunakan pada penelitian ini adalah dengan uji Kruskal-Wallis. Hasil pada penelitian menunjukkan bahwa tidak terdapat perbedaan Abnormal Return pada sektor-sektor saham pada cum dividend date. Penelitian ini juga menunjukkan bahwa tidak terdapat perbedaan Trading Volume Activity pada sebelum cum dividend date, ex-dividend date dan sesudah ex-dividend date. Hal tersebut menunjukkan bahwa peristiwa cum dividend date belum menjadi pertimbangan bagi investor untuk berinvestasi.
\end{abstract}

Kata Kunci: Abnormal Return, Cum Dividend Date, Dividen, Trading Volume Activity.

\begin{abstract}
The purpose of this research is to analyze the difference of Abnormal Return and Trading Volume Activity in each sector of shares around cum dividend date. The population in this study are all companies listed on the Indonesia Stock Exchange (IDX), the sampling is done by purpusive sampling method and obtained 156 samples. The method of analysis used in this study is by Kruskal-Wallis test. The results showed that there was no difference of Abnormal Return on stock sectors on cum dividend date. This research also shows that there is no difference of Trading Volume Activity before before cum dividend date, ex-dividend date and after ex-dividend date. It shows that the cum dividend date event has not become a consideration for investors to invest.
\end{abstract}

Keywords: Abnormal Return, Cum Dividend Date, Dividend, Trading Volume Activity.

\section{Pendahuluan}

Harga-harga saham dalam pasar modal berubah-ubah setiap waktu Hal ini dikarenakan adanya permintaan dan penawaran dari para investor dalam pasar modal. Keputusan investor untuk menjual atau membeli dipengaruhi oleh informasi dan pengetahuan yang dimiliki oleh investor. Informasi dalam hal ini dapat berupa informasi yang berasal dari luar perusahaan maupun dari dalam perusahaan. Informasi yang berasal dari luar perusahaan diantaranya makroekonomi, sosial maupun kondisi politik dan keamanan, sedangkan informasi yang berasal dari dalam perusahaan diantaranya laporan keuangan, laporan laba dan pengumuman dividen.

Peraturan KSEI Nomor KEP-0013/DIR/KSEI/0612 tahun 2012 menyebutkan bahwa corporate action adalah setiap tindakan penerbit efek yang memberikan hak kepada seluruh pemilik manfaat atas efek dari jenis dan kelas yang sama seperti hak untuk memperoleh dividen tunai, dividen saham, bunga, saham bonus, Hak Memesan Efek Terlebih dahulu, waran dan hak-hak lainnya. Singkatnya tindakan perusahaan yang direspon oleh investor dikenal dengan corporate action. Investor menjadikan tindakan perusahaan tersebut sebagai salah satu informasi untuk keputusan investasinya. Salah satu peristiwa yang dianggap sebagai corporate actioan adalah pengumuman pembagian dividen. Hal ini dapat terjadi karena investor ingin mendapatkan keuntungan. Keuntungan yang diharapkan oleh investor dapat berupa keuntungan dari pembagian dividen maupun keuntungan dari selisih antara harga jual dan harga beli (capital gain). Pengumuman pembagian dividen menjadi salah satu peristiwa yang menyebabkan perubahan harga saham dan volume perdagangan saham.

Secara umum dividen adalah bagian dari keuntungan perusahaan yang dibagikan kepada pemegang saham. Dividen yang dibagikan dapat berupa dividen tunai maupun dividen saham. Menurut Fadah (2013:143), dividen tunai merupakan dividen yang dibagikan dalam bentuk uang tunai, sedangkan dividen saham merupakan dividen yang dibagikan dalam bentuk saham. Informasi yang terkandung pada pengumuman dividen dapat meminimalisir asimetris informasi antara investor dan manajemen. Menurut dividend signalling theory pengumuman dividen mengandung sinyal tentang keadaan perusahaan (Brigham dan Houston, 2006:2015).

Salah satu dasar teori untuk menganalisis tentang informasi yang dapat mempengaruhi harga saham adalah teori pasar efisien atau efficient market hypothesis. Fama (1970), dalam Jogianto (2014:559), mendefinisikan pasar yang efisien sebagai pasar yang harga-harga sekuritasnya mencerminkan secara penuh informasi yang tersedia. Fama mengelompokkan tiga bentuk efisiensi pasar berdasarkan

\footnotetext{
* Corresponding author
} 
informasi yang tersedia, yaitu efisiensi pasar bentuk lemah (weak form), efisiensi pasar bentuk setengah kuat (semistrong form) dan efisiensi pasar bentuk kuat (strong form) (Jogianto, 2014:548). Pembagian bentuk pasar tersebut didasarkan pada sejauh mana dan seberapa cepat pasar bereaksi penyerap informasi yang ada (Gumanti, 2011:329). Metode untuk mengetahui dampak dari suatu peristiwa terhadap harga saham dikenal dengan event study. Menurut Jogianto (2014:585), studi peristiwa merupakan studi yang mempelajari reaksi pasar terhadap suatu peristiwa yang informasinya dipublikasikan sebagai suatu pengumuman. Reaksi pasar ini ditunjukkan dengan adanya perubahan harga saham dengan ada tidaknya Abnormal Return dan volume perdagangan saham dengan melihat Trading Volume Activity. Perubahan tersebut terjadi karena investor merespon dari informasi yang diumumkan.

Respon investor dapat dilihat pada tanggal-tanggal disekitar peristiwa berlangsung. Pembagian dividen terbagi menjadi beberapa tahapan. Tahapan pembayaran dividen yang dirangkum dari Brealey et.al yaitu, Tanggal Deklarasi (date of declaration), Cum Dividend Date, Tanggal Tanpa Dividen (Ex-dividend date), Tanggal Pencatatan (date of record) dan Tanggal Pembayaran (Date of Payment). Secara singkat proses pembagian dividen melalui Pengumuman secara resmi dari perusahaan, investor yang membeli saham sampai tanggal cum dividend date akan tercatat sebagai penerima dividen, sehari setelah cum dividend date merupakan hari di mana hak untuk mendapat dividen telah tidak ada (exdividend date), kemudian investor yang mendapat dividen sebelum cum dividend date dicatat oleh perusahaan, tahap yang terakhir adalah pembayaran dividen. Peristiwa yang sering diteliti adalah pada Pengumuman Pembagian Dividen dan Ex-Dividend Date.

Beberapa penelitian yang berkaitan dengan reaksi pasar pada peristiwa cum dividend date telah dilakukan. Misalnya, pasar bereaksi pada peristiwa cum dividend date (Sakti, 2014 dan Na'im 2015). Penelitian lain menunjukkan bahwa pasar tidak bereaksi pada peristiwa cum dividend date atau tidak terdapat abnormal return dan volume aktivitas perdagangan pada sekitar peristiwa tersebut (Handoko, 2016). Penelitian Putra dan Sujana (2014) juga menunjukkan bahwa pasar tidak bereaksi pengumuman dividen, namun reaksi pasar ditemukan pada cum dividend date.

Penelitian ini mencoba untuk menganalisis perbedadaan ratarata pada sebelum cum dividend date, cum dividend date, exdividend date dan sesudah ex-dividend date pada sektorsektor saham. Waktu yang dipilih sebagai pengamatan adalah tahun 2016, untuk hasil yang lebih baru. Populasi dipilih semua perusahaan yang terdaftar di Bursa Efek Indonesia karena lebih bervariasi likuiditas sahamnya.

\section{Pengembangan Hipotesis}

Cum dividend date merupakan waktu di mana hak untuk mendapat dividen melekat pada saham. Menurut dividend signalling theory keputusan pembagian dividen mengandung kandungan informasi tentang prospek perusahaan di masa yang akan datang. Investor yang menyukai dividen akan melakukan pembelian disekitar cum dividend date. Sakti (2014) dan Na'im (2015) menyimpulkan bahwa cum dividend date memiliki kandungan informasi. Berdasarkan uraian tersebut, peneliti mengajukan hipotesis sebagai berikut :

$\mathrm{H}_{1}$ : Ada perbedaan rata-rata abnormal return sebelum cum dividend date, cum dividend date, ex-dividend date dan sesudah ex-dividend date pada sektor-sektor saham.

Volume akativitas perdagangan merupakan perbandingan antara jumlah saham yang diperdagangkan dengan jumlah saham beredar. Suatu informasi yang dianggap dapat mempengaruhi penialian investor akan menyebabkan aktivitas perdagangan berfluktuasi. Na'im (2015), menyimpulkan bahwa pasar bereaksi pasda hari di sekitar cum dividend date, dengan indikator aktivitas perdagangan. Berdasarkan uraian tersebut peneliti mengajukan hipotesis sebagai berikut :

$\mathrm{H}_{2}$ : Ada perbedaan rata-rata trading volume activity sebelum cum dividend date, cum dividend date, ex-dividend date dan sesudah ex-dividend date pada sektor-sektor saham.

\section{Metode}

\section{Rancangan Penelitian}

Penelitian ini adalah penelitian kuantitatif berbasis eksplanatori yaitu penelitian dengan tujuan memahami lebih jauh permasalahan yang diteliti dan mengembangkan hipotesis penelitian. Secara khusus, penelitian ini menganalisis perbedaan abnormal return dan trading volume activity pada sekitar cum dividend date dengan mempertimbangkan sektor saham.

\section{Jenis dan Sumber Data}

Data yang digunakan pada penelitian ini adalah data sekunder berupa harga penutupan saham perusahaan yang membagikan dividen pada tahun 2016. Data tersebut didapat dari wabside finance.yahoo.com dan www.duniainvestasi.com. Daftar sektor-sektor saham pada Bursa Efek Indonesia didapat dari www.idx.co.id.

\section{Populasi dan Sampel}

Populasi pada penelitian ini adalah semua perusahaan yang tercatat pada Bursa Efek Indonesia, peneliti menggunakan seluruh saham dengan pertimbangan agar lebih bervariasi tingkat likuiditasnya. Teknik pengambilan sampel menggunakan Purpusive Sampling dengan kriteria, sampel merupakan perusahaan yang membagikan dividen pada tahun 2016, sampel bukan termasuk perusahaan yang membagi dividen interim, dan sampel bukan termasuk saham tidur. Sampel yang didapat pada penelitian ini adalah 156 perusahaan.

\section{Metode Analisis Data}

Metode analisis yang digunakan pada penelitian ini adalah analisis uji Kruskal-Wallis. Data harga penutupan (close price) dan volume perdagangan dihitung dengan rumus variabel-variabel yang digunakan. Variabel Abnormal Return dihitung dengan metode market model. 
Tabel 1. Proses Penentuan Sampel

\begin{tabular}{lc}
\hline \multicolumn{1}{c}{ Keterangan } & Jumlah \\
\hline $\begin{array}{l}\text { Perusahaan yang terdaftar dalam Bursa Efek } \\
\text { Indonesia }\end{array}$ & 540 \\
Pengumuman pembagian Dividen tahun 2016 & 257 \\
Perusahaan yang membagikan dividen interim & 36 \\
Saham tidur & 65 \\
Sampel akhir & 156 \\
\hline
\end{tabular}

Sumber: www.eddyelly.com, www.idx.com, data diolah.

Pengambilan sampel penelitian ini ditetapkan dengan metode purpusive sampling dengan kriteria yang telah ditetapkan sebelumnya. Berdasarkan kriteria tersebut Perusahaan yang termasuk dalam sampel adalah 156 perusahaan. Sampel tersebut terdiri dari sembilan sekor.

Tabel 2 menyajikan jumlah sampel berdasarkan sektor-sektor saham.

Tabel 2. Jumlah Sampel Pada Sektor Saham

\begin{tabular}{lccc}
\hline \multicolumn{1}{c}{ Sektor Saham } & $\begin{array}{c}\text { Jumlah } \\
\text { Populasi }\end{array}$ & $\begin{array}{c}\text { Jumlah } \\
\text { Perusahaan }\end{array}$ & $\begin{array}{c}\% \text { dari } \\
\text { total }\end{array}$ \\
\hline Pertanian & 21 & 8 & $5 \%$ \\
Pertambangan & 43 & 8 & $5 \%$ \\
Industri Dasar dan Kimia & 66 & 23 & $15 \%$ \\
Aneka Industri & 42 & 14 & $9 \%$ \\
Industri Barang Konsumsi & 39 & 16 & $10 \%$ \\
$\begin{array}{l}\text { Properti, Real Estate, dan } \\
\text { Kontruksi Bangunan }\end{array}$ & 63 & 19 & $12 \%$ \\
$\begin{array}{l}\text { Infrastruktur, Utilitas dan } \\
\text { Transportasi }\end{array}$ & 55 & 13 & $8 \%$ \\
$\begin{array}{l}\text { Keuangan } \\
\text { Perdagangan, Jasa dan }\end{array}$ & 89 & 20 & $13 \%$ \\
Investasi & 122 & 35 & $22 \%$ \\
\hline \multicolumn{1}{c}{ Total } & 540 & 35 & $22 \%$ \\
\hline
\end{tabular}

Sumber: www.idx.co.id data diolah.

Deskripsi statistik data digunakan untuk menyimpulkan dan mepresentasikan data, untuk memberi gambaran atau penjelasan karakteristik dari data yang digunakan.

Tabel 3. Deskripsi Statistik Data Abnormal Return $(\mathrm{n}=156)$

\begin{tabular}{lccccc}
\hline Keterangan & Mean & Median & $\begin{array}{c}\text { Standart } \\
\text { Deviation }\end{array}$ & AR+ & AR- \\
\hline Sebelum & $-0,0030$ & $-0,0007$ & 0,0604 & 75 & 81 \\
Cum Date & $-0,0023$ & $-0,0025$ & 0,0273 & 64 & 92 \\
Ex-date & $-0,0154$ & $-0,0130$ & 0,0391 & 37 & 119 \\
Sesudah & $-0,0042$ & $-0,0017$ & 0,0262 & 68 & 88 \\
\hline
\end{tabular}

Sumber: data diolah, 2017.

Tabel 3. menunjukkan bahwa rata-rata terendah terjadi pada ex-dividend date sebesar $-1,54 \%$. Hal ini menunjukkan bahwa rata-rata keuntungan pada peristiwa ex-dividen date lebih rendah dibandingkan hari lainnya. Secara rata-rata investor mengalami rugi, karena nilai rata-rata pada empat periode pengamatan bernilai negatif. Hal tersebut dapat dilihat dari jumlah perusahaan yang mendapatkan Abnormal Return negatif lebih banyak.

Tabel 4. Rata-rata Abnormal Return

\begin{tabular}{|c|c|c|c|c|}
\hline Sektor & Sebelum & $\begin{array}{c}\text { Cum } \\
\text { dividend }\end{array}$ & $\begin{array}{c}\text { Ex- } \\
\text { dividend }\end{array}$ & Sesudah \\
\hline Pertanian & $-0,0106$ & $-0,0012$ & $-0,0120$ & $-0,0018$ \\
\hline Pertambangan & 0,0097 & $-0,0025$ & $-0,0239$ & 0,0053 \\
\hline $\begin{array}{l}\text { Industri Dasar dan } \\
\text { Kimia }\end{array}$ & $-0,0255$ & 0,0004 & $-0,0015$ & $-0,0006$ \\
\hline Aneka Industri & 0,0100 & $-0,0109$ & $-0,0163$ & 0,0000 \\
\hline $\begin{array}{l}\text { Industri } \quad \text { Barang } \\
\text { Konsumsi }\end{array}$ & $-0,0160$ & $-0,0117$ & $-0,0253$ & $-0,0148$ \\
\hline $\begin{array}{l}\text { Properti, Rela Estate } \\
\text { dan } \\
\text { Bangunan }\end{array}$ & $-0,0041$ & $-0,0017$ & $-0,0094$ & $-0,0030$ \\
\hline $\begin{array}{l}\text { Infrastruktur, Utilitas } \\
\text { dan Transportasi }\end{array}$ & $-0,0023$ & $-0,0083$ & $-0,0195$ & 0,0065 \\
\hline Keuangan & $-0,0090$ & 0,0015 & $-0,0173$ & $-0,0132$ \\
\hline $\begin{array}{l}\text { Perdagangan, } \\
\text { dan Investasi }\end{array}$ & $-0,0051$ & 0,0034 & $-0,0193$ & $-0,0056$ \\
\hline Rata-rata & $-0,0030$ & $-0,0023$ & $-0,0154$ & $-0,0042$ \\
\hline
\end{tabular}

Sumber: data diolah, 2017.

Tabel 4 menyajikan rekapitulasi dari rata-rata Abnormal Retun. Pada sebelum cum dividend date, Abnormal Return tertinggi terjadi pada sektor Aneka Industri sebesar 1\%, sedangkan rata-rata terendah terjadi pada sektor Industri Dasar Kimia sebesar -2,5\%. Pada cum dividend date, Abnormal Return tertinggi terjadi pada sektor Perdagangan Jasa dan Investasi sebesar $0,34 \%$, sedangkan terendah terjadi pada sektor Industri Barang Konsumsi sebesar -1,17\%. Pada ex-dividen date, Abnormal Return tertinggi terjadi pada sektor Industri Dasar Kimia sebesar $-0,15 \%$, sedangkan terendah pada sektor Industri Barang Konsumsi sebesar $-2,53 \%$. Pada sesudah ex-dividendate rata-rata Abnormal Return tertinggi terjadi pada sektor Infrastruktur, Utilitas dan Transportasi sebesar $0,65 \%$, sedangkan terendah terjadi pada Industri Barang Konsumsi sebesar -1,48\%.

Tabel 5. Deskriptif Statistik Data Trading Volume Activity $(\mathrm{n}=156)$

\begin{tabular}{lccccc}
\hline Keterangan & Min & Max & Mean & Median & $\begin{array}{c}\text { Standart } \\
\text { Deviation }\end{array}$ \\
\hline Sebelum & 0,0000 & 0,0958 & 0,0045 & 0,0005 & 0,0120 \\
Cum date & $-0,0055$ & 0,0900 & 0,0047 & 0,0006 & 0,0128 \\
Ex-dividend & $-0,0187$ & 0,0579 & 0,0032 & 0,0004 & 0,0083 \\
Sesudah & 0,0000 & 0,1398 & 0,0034 & 0,0004 & 0,0125 \\
\hline
\end{tabular}

Sumber: data diolah, 2017.

Deskriptif statistik Trading Volume Activity yang disajikan pada Tabel 5. menunjukkan bahwa rata-rata terendah terjadi pada peristiwa ex-dividen date sebesar 0,0032, hal ini menunjukkan bahwa rata-rata volume perdagangan pada peristiwa ex-dividen date lebih rendah dari hari lainnya. Nilai Trading Volume Activity terendah juga terjadi pada exdividen date, sebesar $-0,0187$, hal ini menunjukkan bahwa volume perdagangan terendah terjadi pada ex-dividen date. 
Tabel 6. Ringkasan Hasil Uji Kruskal-Wallis Pada Abnormal Return

\begin{tabular}{lccccc}
\hline Keterangan & Mean & Median & $\begin{array}{c}\text { Tingkat } \\
\text { Signifik } \\
\text { asi }\end{array}$ & Sig. & Kesimpulan \\
\hline Sebelum & $-0,0030$ & $-0,0007$ & 0,05 & 0,502 & $\mathrm{H}_{01}$ Diterima \\
$\begin{array}{l}\text { Cum } \\
\text { dividend }\end{array}$ & $-0,0023$ & $-0,0025$ & 0,05 & 0,398 & $\mathrm{H}_{01}$ Diterima \\
Ex-dividend & $-0,0154$ & $-0,0130$ & 0,05 & 0,759 & $\mathrm{H}_{01}$ Diterima \\
Sesudah & $-0,0042$ & $-0,0017$ & 0,05 & 0,451 & $\mathrm{H}_{01}$ Diterima \\
\hline
\end{tabular}

Sumber: data diolah, 2017.

Hasil uji Kruskal-Wallis yang disajikan pada Tabel 6. Hasil uji Kruskal-Wallis dengan tingkat signifikasi 0,05 menunjukkan bahwa Abnormal Return pada sektor-sektor dalam pasar modal tidak berbeda pada periode pengamatan sebelum cum dividend date, cum dividend date, ex-dividenda date dan sesudah ex-dividen date. Hal tersebut menolak hipotesis yang pertama yaitu ada perbedaan rata-rata Abnormal Return sebelum cum dividend date, cum dividend date, ex-dividen date dan sesudah ex-dividen date.

Tabel 7. menyajikan rekapitulasi dari uji beda rata-rata (uji-t) satu sampel. Uji beda tersebut dilakukan untuk melihat dan mengkonfirmasi hasil dari uji Kruskal-Wallis, bagaimana jika dilihat dari rata-rata setiap sektor pada hari pengamatan. Hal ini dilakukan untuk menyakinkan dan menguatkan hasil dari uji Kruskal-Wallis. Hasil dari uji $\mathrm{t}$ satu sampel data Abnormal Return yang signifikan pada tingkat 5\% adalah Abnormal Return yang terjadi pada ex-dividen date pada sektor Aneka Industri, Keuangan dan sektor Perdagangan, Jasa dan Investasi. Hasil ini menunjukkan bahwa Abnormal Return hanya terjadi pada ketiga sektor tersebut.

Tabel 7. Rekapitulasi Uji Beda Rata-rata (Uji-t) Satu Sampel $(\alpha=5 \%)$

\begin{tabular}{|c|c|c|c|c|c|}
\hline Sektor & $t_{\text {tabel }}$ & Sebelum & $\begin{array}{c}\text { Cum } \\
\text { dividend }\end{array}$ & $\begin{array}{c}E x- \\
\text { dividend }\end{array}$ & Sesudah \\
\hline Pertanian & 2,365 & $-0,881$ & $-0,157$ & $-1,993$ & $-0,537$ \\
\hline Pertambangan & 2,365 & 1,609 & $-0,196$ & $-1,638$ & 1,659 \\
\hline $\begin{array}{l}\text { Industri Dasar } \\
\text { dan Kimia }\end{array}$ & 2,074 & $-0,901$ & 0,060 & $-0,150$ & $-0,190$ \\
\hline Aneka Industri & 2,160 & 1,255 & $-2,042$ & $-2,460 *$ & $-0,012$ \\
\hline $\begin{array}{l}\text { Industri Barang } \\
\text { Konsumsi }\end{array}$ & 2,131 & $-1,309$ & $-1,097$ & $-2,112$ & $-0,984$ \\
\hline $\begin{array}{l}\text { Properti, Real } \\
\text { Estate dan } \\
\text { Konstruksi } \\
\text { Bangunan }\end{array}$ & 2,101 & $-1,378$ & $-0,313$ & $-1,263$ & $-0,891$ \\
\hline $\begin{array}{l}\text { Infrastruktur, } \\
\text { Utilitas dan } \\
\text { Transportasi }\end{array}$ & 2,179 & $-0,275$ & $-1,496$ & $-1,733$ & 1,215 \\
\hline Keuangan & 2,093 & 0,882 & 0,392 & $2,166^{*}$ & $-1,970$ \\
\hline $\begin{array}{l}\text { Perdagangan, } \\
\text { Jasa dan } \\
\text { Investasi }\end{array}$ & 2,032 & 1,146 & 0,758 & $-2,771^{*}$ & $-1,810$ \\
\hline
\end{tabular}

Sumber: data diolah, 2017.

* $t_{\text {hitung }}$ yang signifikan
Tabel 8. Ringkasan Hasil Analisis Kruskal-Wallis Pada Trading Volume Activity

\begin{tabular}{lccl}
\hline Keterangan & $\begin{array}{l}\text { Tingkat } \\
\text { Signifikasi }\end{array}$ & Sig. & Kesimpulan \\
\hline Sebelum & 0,05 & 0,14 & $\mathrm{H}_{02}$ Diterima \\
Cum dividend & 0,05 & $0,04^{*}$ & $\mathrm{H}_{02}$ Ditolak \\
Ex-divided & 0,05 & 0,07 & $\mathrm{H}_{02}$ Diterima \\
Sesudah & 0,05 & 0,05 & $\mathrm{H}_{02}$ Diterima \\
\hline
\end{tabular}

Sumber: data diolah, 2017.

*signifikan dengan $\alpha \leq 5 \%$.

Tabel 8. menunjukkan hasil dari uji Kruskal-Wallis. Dari tabel tersebut terdapat informasi bahwa nilai signifikasi pada periode pengamatan di sektor-sektor saham pada sebelum cum dividend date, ex-divided date dan sesudah ex-dividend date tidak berbeda. Namun hasil pada cum dividend date menunjukkan hasil yang berbeda. Hal ini telah menjawab hipotesis yang kedua yaitu ada perbedaan rata-rata Trading Volume Activity pada sebelum cum dividend date, cum dividend date, ex-divided date dan sesudah ex-dividend date.

\section{Hasil dan Pembahasan}

Analisis berbedaan Abnormal Return pada sektor saham di sekitar peristiwa cum dividend date menunjukkan bahwa tidak terjadi perbedaan. Hal ini dapat dilihat dari hasil pengujian yang dilakukan. Nilai signifikasi yang dihasilkan dari uji Kruskal-Wallis lebih tinggi dari tingkat signifikasi yang ditentukan sebelumnya. Hal ini menunjukkan bahwa secara umum peristiwa pembagian dividen tidak dianggap sebagai peristiwa yang dapat menjadi pertimbangan dalam melakukan pembelian saham di semua sektor. Secara keseluruhan, rata-rata Abnormal Return terjadi perubahan, Abnormal Return mengalami kenaikan pada cum dividend date, kemudian mengalami penurunan pada ex-dividend date dan kembali naik setelah ex-dividend date.

Penelitian ini menerima hipotesis penelitian yang menyatakan terdapat perbedaan Abnormal Return pada sekitar cum dividend date pada sektor saham. Analisis yang dilakukan dengan mengamati masing-masing sektor secara terpisah, juga menunjukkan bahwa perbedaan rata-rata Abnormal Return hanya pada ex-dividend date yang signifikan. Rata-rata yang signifikan tersebut terdapat pada sektor Aneka Industri, Keuangan dan pada sektor Perdagangan Jasa dan Investasi. Pada sektor Aneka Industri, Keuangan, dan Perdagangan Jasa dan Investasi terdapat perbedaan Abnormal Return, karena kemungkinan investor lebih tertarik untuk berinvesi pada sektor tersebut. Hal ini didukung oleh pernyataan dari Badan Pusat Statistik (BPS) bahwa pertembuhan ekonomi pada sektor Keuangan, Informasi dan Konsumsi, dan Jasa non keuangan memiliki pertimbuhan yang paling tinggi pada tahun 2016. Hal ini sejalan dengan penelitian Putra dan Sujana (2014) dan penelitian Handoko (2016) bahwa tidak ada perbedaan Abnormal Return pada sekitar cum dividend date.

Tidak ditemukannya perbedaan Abnormal Return pada masing-masing sektor saham menunjukkan bahwa rata-rata investor tidak mempertimbangkan sektor saham pada saat peristiwa pembagian dividen. Kondisi tersebut dapat disebabkan karena faktor-faktor lain yang menjadi 
pertimbangan dalam berinvestasi dalam pasar modal misalnya, investor tidak mempertimbangkan sektor untuk berinvestasi karena pertumbuhan pada semua sektor mengalami peningkatan dan faktor lainnya. Penelitian ini berfokus pada satu event saja, yaitu pada peristiwa pembagian dividen saja dan mengesampingkan informasi yang lain.

Hasil pengujian hipotesis yang kedua menunjukkan bahwa pada peristiwa pembagian dividen, investor bereaksi pada cum dividend date. Hal ini dapat dilihat dari hasil analisis yang dilakukan pada data Trading Volume Activity. Hasil uji Kruskal-Wallis yang dilakukan, menunjukkan terjadi perbedaan Trading Volume Activity pada sektor-sektor saham pada peristiwa cum dividend date. Hasil tersebut menunjukkan bahwa pada peristiwa cum dividend date hipotesis nol ditolak. Hal ini sejalan dengan penelitian $\mathrm{Na}$ 'im (2015) yang menunjukkan terdapat reaksi pasar pada peristiwa cum dividend date. Namun, pada sebelum cum dividend date, ex-dividend date dan sesudah ex-dividend date tidak terjadi perbedaan Trading Volume Activity di sektorsektor saham. Adanya perbedaan Trading Volume Activity kemungkinan karena pada saat cum dividend date, investor banyak melakukan transaksi, sehingga volume perdagangan meningkat. Hal ini sejalan dengan penelitian Putra dan Sujana (2014) dan Penelitian Handoko (2016) bahwa tidak ada perbedaan Trading Volume Activity pada sekitar peristiwa cum dividend date.

Reaksi investor pada peristiwa pembagian dividen terjadi pada peristiwa cum dividend date, hal ini terlihat dari hasil uji Kruskal-Wallis. Hasil uji Kruskal-Wallis menunjukkan bahwa pada sebelum cum dividend date, ex-dividend date dan sesudah ex-dividend date tidak terdapat perbedaan Trading Volume Activity pada sektor-sektor saham. Perbedaan Trading Volume Activity pada cum dividend date menunjukkan bahwa investor mempertimbangkan dalam sektor apa mereka berinvestasi. Hal tersebut juga dapat menunjukkan bahwa investor ingin mendapatkan dividen pada sektor saham tertentu sehingga pada cum dividend date terjadi perbedaan Trading Volume Activity yang signifikan.

\section{Simpulan}

Berdasarkan hasil analisis data, pembahasan dan tujuan penelitian untuk menganalisis perbedaan Abnormal Return dan Trading Volume Activity pada sekitar peristiwa cum dividen date pada sektor-sektor saham ditarik kesimpulan sebagai berikut.

Abnormal return tidak berbeda pada sebelum cum dividend date, cum dividend date, ex-dividen date dan setelah exdividend date. Dengan demikian dapat dinyatakan bahwa event pembagian dividen belum menjadi pertimbangan investor.

Tidak terdapat perbedaan Trading Volume Activity pada sebelum cum dividend date, ex-dividend date dan sesudah exdividend date. Namun terdapat perbedaan Trading Volume Activity pada cum dividend date. Hal ini menunjukkan bahwa volume perdagangan saham tidak banyak berubah pada sebelum cum dividend date, ex-dividend date dan sesudah ex-dividend date. Namun, perubahan ditemukan pada cum dividend date.

\section{Referensi}

Brigham Eugene F. dan Houston Joel F. 2011. Dasar-dasar Manajemen Keuangan. Edisi Kesebelas. Jakarta: Salemba Empat.

Dunia Investasi. 2016. http://www.duniainvestasi.com [April-Mei 2016]

Eddy Elly. 2017. Jadwal Dividen 2016. http://www.eddyelly.com/2016/02/jadwal-dividen-2016.html $\quad[14$ Februari 2016]

Fadah, Isti, 2013. Manajemen Keuangan (Suatu Konsep Dasar). Mojokerto: Insan Global.

Gumanti, Tatang Ary. 2011. Manajemen Investasi Konsep, Teori dan Aplikasi. Jakarta: Mitra Wacana Media.

Handoko, Liza. 2016. Analisis Reaksi Pasar Terhadap Pengumuman Dividan Perusahaan LQ45. Jurnal Riset Bisnis dan Manajemen. Vol 4. No.3: 269-276.

Indonesia Stock Exchange. 2017. www.idx.co.id/ [Mei 2017]

Jogianto, Hartono. 2014. Teori Portofolio dan Analisis Investasi. Edisi Kedelapan. Yogyakarta: BPFEUGM-Yogyakarta.

Na'im Mulfi Muhammad. 2015. Ananlisis Reaksi Pasar Atas Pengumuman Cum Dividen (Studi Pada Saham Yang Terdaftar di Jakarta Islamic Index Tahun 2012-1013). Jurnal Ekonomi Syariah Teori dan Terapan. Vol. 2. No. 1: 61-76.

Perubahan Peraturan KSEI Tentang Jasa Kustodian Sentral Nomor : KEP0013/DIR/KSEI/0612. [31 Oktober 2016]

Putra dan Sujana. 2014. Analisis Reaksi pasar Terhadap Pengumuman Dividen Tunai Pada Perusahaan Yang Terdaftar Di Bursa Efek Indonesia. E-Journal Akuntansi Universitas Udayana. Vol 8. No.2: 118-136.

Sakti, Sagung Anegsa. 2104. Perbandingan Tingkat Keuntungan Harian yang Diharapkan, Variabilitas Tingkat Keuntungan, dan Aktivitas Volume Perdagangan Saham yang Terdaftar di Indeks LQ45 antara Sebelum dengan Sesudah Cum Dividend Date. Tidak Dipublikasikan. Skripsi. Jakarta: Universitas Muhammad Husni Tamrin.

Yahoo Finance. 2016. https://finance.yahoo.com/ [April - Mei 2016]. 